\title{
Absence of Non-Carious Cervical Lesions (NCCLs) in a Chilean Pre-Columbian Sample with Severe Occlusal Tooth Wear
}

\author{
Ausencia de Lesiones Cervicales no Cariosas (NCCLs) en una \\ Muestra Chilena Precolombina con Severo Desgaste Oclusal
}

I. Urzúa*; R. Cabello*; G. Rodríguez*; J. Sánchez; ;. Faleiros* \& A. Pacheco*

URZÚA, I.; CABELLO, R.; RODRÍGUEZ, G.; SÁNCHEZ, J.; FALEIROS, S. \& PACHECO, A. Absence of non-carious cervical lesions (NCCLs) in a Chilean pre-Columbian sample with severe occlusal tooth wear. Int. J. Odontostomat., 9(1):59-64, 2015.

ABSTRACT: This study evaluates the non-carious cervical lesions (NCCLs) and the occlusal tooth wear in a preColumbian sample ( $n=67$, adults) from San Pedro de Atacama (North of Chile, 400-1300 BCE). The cervical regions of tooth were observed for loss of enamel and/or dentine in order to identify them as NCCLs and the tooth wear was characterized by the Basic Erosive Wear Examination (BEWE) index. None of the individuals analyzed presented NCCLs, whereas the 98.5\% (66/67) of them showed occlusal wear. The mean BEWE index was 2.5, indicating severe dental wear (3 being the highest possible score of BEWE). This lack of relation among severe tooth wear and NCCLs gives support to the idea of loss of crown height reduces cervical stress and develop of NCCLs in archaeological populations.

KEY WORDS: non-carious cervical lesions, abfraction, tooth wear, Pre-Columbian, Chile.

\section{INTRODUCTION}

Tooth wear has been classified into attrition, abrasion and erosion (Bartlett \& Shah, 2006). Attrition is the loss of enamel and dentin by tooth-to-tooth contact, abrasion is the loss of tooth substance by factors not related to tooth contact, and erosion is the loss of dental hard tissues by chemical action other than bacterial processes (Pindborg, 1970a, 1970b; Lewis \& Smith, 1973). Some researchers recommend supplant erosion by "biocorrosion" because its include proteolysis and electrochemical action (Grippo et al., 2012).

The attrition, abrasion and erosion may act synchronously or sequentially, synergistically or additively, or in conjunction with other entities (Litonjua et al., 2003a), but in general its effects are observed mainly at the oclusal surfaces.

Ancient human remains commonly show severe tooth wear in the oclusal surfaces resulting from attrition and abrasion (Smith, 1972; Larsen, 1999). In contrast, postindustrial populations show mild dental wear. The western lifestyle of contemporary people produces little abrasion and their tooth wear results mainly from erosion (Kaidonis, 2008; Kaidonis et al., 2012).

The non-carious cervical lesions (NCCLs) are defects in the buccal/vestibular cervical region of the tooth (Wood et al., 2008). They are more pronounced on incisors, canines, and premolars and more prevalent in the maxilla than the mandible (Kitchin, 1941).

The etiology of NCCLs has been widely discussed in the last twenty years, and different factors have been proposed. These include erosive agents (endogenous or exogenous), abrasive (tooth brushing force/ frequency), and occlusal forces (Wood et al.). Even, a multifactorial etiology has been proposed (Litonjua et al., 2003b; Grippo et al.).

\footnotetext{
"Cariology Area, Department of Restorative Dentistry, Faculty of Dentistry, Universidad de Chile, Santiago, Chile.

" PhD student Department of Archaeology, University of Durham, Durham, United Kingdom.
} 
Whereas the combination of erosion and abrasion could result in NCCLs (Bartlett \& Shah), the predominant explanation is that horizontal loads due to mastication and malocclusion produce flexure and tensile forces leading to cervical tooth breakdown (Lee \& Eakle, 1984). This breakdown was named abfraction (Grippo, 1991). This term has been matter of controversy and it is not accepted by all scholars (Michael et al., 2009). In order to avoid problems derived from naming a lesion according to an etiology, in this paper we will maintain the term NCCLs (Grippo et al.).

The NCCLs are considered modern-day conditions (Kaidonis et al., 2012). Whereas some researchers suggest the importance of habits (tooth brush) and/or exposition to erosive agents in modern populations (Aubry et al., 2003), others suggest that their mild dental wear promotes the forces that produce NCCLs (Benazzi et al., 2013). Clinical studies have shown opposite conclusion. Some consider the area of occlusal contact and the action of excessive occlusal forces as significant etiologic agents in the appearance of cervical lesions (Takehara et al., 2008), and others found no association between occlusal stress and presence and progression of abfraction lesions (Litonjua et al., 2004). A review of clinical studies stated that the NCCLs and occlusion do not have a causal relation (Senna et al., 2012). This does not mean that there is no association, but that the role of occlusion in NCCLs etiology is not yet determinate because evaluation and confounding bias and that additional research is required to support or disprove if NCCLs are caused by occlusal load.

Whereas NCCLs is commonly found in different modern populations, there is little or no evidence of these lesions in worldwide ancient samples (Aaron,
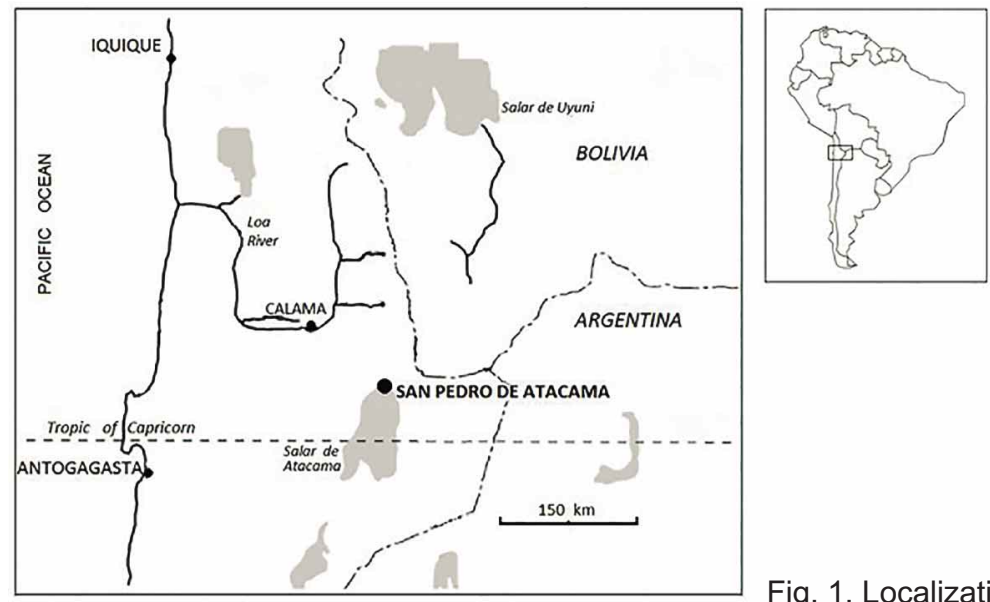

Fig. 1. Localization of San Pedro de Atacama, Chile.
2004; Aubry et al.; Coppa et al., 2007; Kieser et al., 2001; McEvoy et al., 1996; Ritter et al., 2009). This absence of NCCLs in the past have been explained because the lack of tooth brushing abrasion in ancient times or because their diet was basically nonacidogenic. Some argue that the lack of NCCLs in precontemporary populations which show high rates of occlusal wear there is "strong evidence" against the concept that "abfraction" can be caused by occlusal loading alone (Michael et al.). Others pointed out that severe dental wear could "prevent" NCCLs because the loss of cusps may reduce lateral forces and cervical stress (Kieser et al.).

In order to contribute with data from ancient remains in themes of current debate (Michael et al.; Kaidonis et al., 2012), the aim of this study is to report the NCCLs and the occlusal tooth wear in a preColumbian sample and discuss the relation among them. The sample analyzed comprised individuals that inhabited the San Pedro de Atacama Oases (North of Chile) between 400-1400 AD, for whom there is data about dental wear (Costa, 1988; Costa \& Llagostera, 1994; Hubbe et al., 2012), but not about NCCLs. To our knowledge, there have been no studies on this topic on other pre-Columbian samples of Chile.

\section{MATERIAL AND METHOD}

San Pedro de Atacama oases are located in the northeast of Chile (Fig. 1). They are 2400 masl, and surrounded by one of the driest climates on the planet, they have been inhabited for many years. (Torres-Rouff \& Hubbe, 2013). Between 400-1400 AD the oases were inhabited by sedentary groups with horticultural, animal grazing and agricultural practices. A total of 262 adult human remains of these groups are currently curated at the Instituto de Investigaciones Arqueológicas y Museo R. P. Gustavo Le Paige, in the town of San Pedro de Atacama. From the 262 adults, a sample of $67(\mathrm{~N}=67)$ was selected. The inclusion criteria were presence of complete cranium and at least one tooth in each sextant. Age at death was estimated for each one following standard criteria (Buikstra \& Ubelaker, 1994). 
URZÚA, I.; CABELLO, R.; RODRÍGUEZ, G.; SÁNCHEZ, J.; FALEIROS, S. \& PACHECO, A. Absence of non-carious cervical lesions (NCCLs) in a Chilean pre-Columbian sample with severe occlusal tooth wear. Int. J. Odontostomat., 9(1):59-64, 2015.

To identify the NCCLs the cervical regions of the tooth were observed looking for loss of enamel and/or dentine. To quantify the dental wear a modification of the "Basic Erosive Wear Examination - BEWE Index" was used (Table I). The BEWE is a partial scoring system that grades the appearance or severity of tooth wear and records the most affected surface per sextant (Bartlett et al., 2008). In this study the examination was performed on occlusal surfaces for all teeth in each sextant but only the surface with the highest score was recorded in each of them. The advantage of BEWE index includes that it is simple, standardized, and reflects the nature, extent and progression of the defects. Additionally, is a transferable scoring system that can be used with the diagnostic criteria of all existing indices, thus allowing comparisons of prevalence among bioarchaeological and clinical data.

\begin{tabular}{cl} 
Table I. & Basic Erosive Wear Examination Index. \\
\hline Score & Criteria for grading \\
\hline 0 & No erosive tooth wear \\
1 & Initial loss of surface texture \\
2 & $\begin{array}{l}\text { Distinct defect, hard tissue loss } \\
<50 \% \text { of the surface area }\end{array}$ \\
3 & Hard tissue loss $\geq 50 \%$ of the surface area
\end{tabular}

All the observations were carried out by trained dental professionals (IU and JS) with clinical training on the identification of NCCLs and on the tooth wear index. Each cranium and mandible was handled with latex gloves and examined under adequate light and visibility conditions by a single examiner, who registered the data on forms specifically designed. Once all the sextants had been assessed, the total cumulative score was calculated. Statistical analyses were performed using STATA 10.

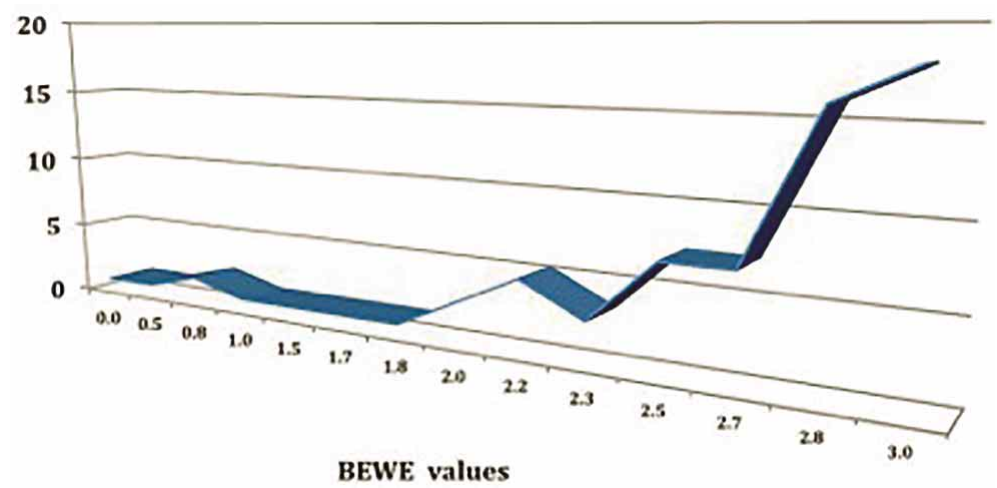

Fig. 2.Distribution of individuals by Basic Erosive Wear Examination (BEWE) values.

\section{RESULTS AND DISCUSSION}

The 67 adults expressed an average age of 28.4 years (SD: 8.39). The number of teeth present in mouth of these individuals showed a wide range from 8 (minimum) to 32 (maximum), with a mean of 22.7 (SD: 5.6). No one NCCLs was found (0/67 individuals).

Dental wear was observed in the $98.5 \%$ of the sample (66/67 individuals). The tooth with wear range from 7 to 32, and the mean of worn tooth was 30.56 (SD: 5.1). Values of BEWE Index per sextant are presented in Table II. The mean of the BEWE Index was 2.5 , indicating severe dental wear. The minimum value registered was 0 and the maximum was 18 .

The Figure 2 shows the frequency of individuals of the sample in relation to their BEWE Index. Table III presents the percentile distribution of the BEWE Index in the sample of study.

Our results about occlusal wear were according previous studies about attrition/abrasion on these archeological groups of San Pedro (Costa; Costa \& Llagostera; Hubbe et al.). These studies identified a pattern of dental wear, with the anterior teeth more affected than posterior, discarded erosive process because they had a non-acidic diet, and explained the severe dental wear because the consumption of hard fibrous foods and the incorporation of exogenous particles (of sand and/or lithic particles derived from grinding devices).

Whereas severe occlusal wear was observed in our sample, none of the analyzed teeth presented signs of cervical tooth material loss. These findings confirm, in this pre-Columbian sample of the San Pedro oases, the inverse relation between severe dental wear and non-carious cervical lesions (NCCLs). More specifically, the lack of relation among NCCLs and oclusal wear.

This lack of relation suggests discarding the severe tooth wear as an indirect evidence of excessive occlusal forces related with development of NCCLs. Moreover, the loss of crown height and a larger occlusal table in fact, leading to a reduction in tension and cervical stress, because occlusal forces are dissipated over the opposing surfaces and directed axially. Therefore, the worn flat reduces the 
Table II. BEWE Index, mean, standard deviation (SD), minimum and maximum values by each sextant and for the total of the sample.

\begin{tabular}{lcccc}
\hline BEWE Index & Mean & SD & $\begin{array}{c}\text { Minimum } \\
\text { value }\end{array}$ & $\begin{array}{c}\text { Maximun } \\
\text { value }\end{array}$ \\
\hline BEWE Sextant 1 & 2.46 & 0.80 & 0 & 3 \\
BEWE Sextant 2 & 2.58 & 0.84 & 0 & 3 \\
BEWE Sextant 3 & 2.49 & 0.82 & 0 & 3 \\
BEWE Sextant 4 & 2.36 & 0.77 & 0 & 3 \\
BEWE Sextant 5 & 2.66 & 0.69 & 0 & 3 \\
BEWE Sextant 6 & 2.45 & 0.70 & 0 & 3 \\
Total BEWE Mean & 2.5 & 3.91 & 0 & 18
\end{tabular}

possibility of NCCLs in "archaeological populations" (Ritter et al.).

The "archaeological time", however, comprise chronological scales from Prehistoric to Middle Ages and even beyond in certain areas. For example, some contemporaneous human groups (v.g. Australian Aboriginals) living essentially a non-industrial way of life (Kaidonis et al., 1993). The dental wear in human groups shows variability according temporal changes and different lifestyles, being the attrition the more analyzed and documented (Deter, 2009; Eshed et al., 2006; Ganss et al., 2002; Kaifu, 1999; Molnar, 1971;
Smith, 1984). The scarce studies of NCCLs in ancient samples (Aaron; Aubry et al.; Coppa et al.; Kieser et al.; McEvoy et al.; Ritter et al.) are not comparable because their different chronology, spatial extent (across several continents, and distinct ecological regions) and the several adaptations of the groups analysed. Because the diversity and combination of factors that affected the dental tissues in the past, this dental evidence should be documented by the entire range of archaeological settings. For the record of NCCLs in archaeological samples, we also recommend to consider observations regarding caries and dental loss, form and severity of dental attrition (Hinton, 1981), extramasticatory dental wear (Molnar, 2011), alveolar bone retractions (Vasconcelos et al., 2006), and changes in the occlusion derived from dental wear (Kaifu, 2000 Kaifu et al., 2003; d'Íncau et al., 2012).

Finally, if the lack of dental wear is the main factor leading to NCCLs on industrialized societies (Benazzi et al.), in order to avoid them, how much dental wear can be seen as acceptable in dental practice (Kaidonis).

Table III. Percentiles of the Basic Erosive Wear Examination (BEWE) index in the sample.

\begin{tabular}{lcccccccccc}
\hline & \multicolumn{10}{c}{ Percentiles } \\
\cline { 2 - 10 } BEWE values & 10 & 20 & 30 & 40 & 50 & 60 & 70 & 80 & 90 & 100 \\
& 9.8 & 13 & 15 & 16 & 17 & 17 & 17 & 18 & 18 & 18 \\
\hline
\end{tabular}

\section{ACKNOWLEDGMENTS}

To the Instituto de Investigaciones Arqueológicas y Museo R.P. Le Paige in San Pedro de Atacama and its staff for permissions and assistance during the data collection.

URZÚA, I.; CABELLO, R.; RODRÍGUEZ, G.; SÁNCHEZ, J.; FALEIROS, S. \& PACHECO, A. Ausencia de lesiones cervicales no cariosas (NCCLs) en una muestra chilena precolombina con severo desgaste oclusal. Int. J. Odontostomat., 9(1):53-58, 2015.

RESUMEN: Este estudio evalúa las lesiones cervicales no cariosas (NCCLs) y el desgaste dental oclusal en una muestra precolombina $(n=67$, adultos) de San Pedro de Atacama (Norte de Chile, 400-1300 AEC). Se analizó la perdida de esmalte y/o dentina en las áreas cervicales de los dientes con el propósito de identificarlas como NCCLs y el desgaste dental fue evaluado según el índice Basic Erosive Wear Examination (BEWE). Ninguno de los individuos analizados presentó NCCLs, mientras el 98,5\% (66/67) de ellos mostró desgaste oclusal. El promedio del índice BEWE fue de 2,5, indicando severo desgaste dental (siendo 3 el puntaje más alto posible). La falta de relación entre severo desgaste dental y NCCLs apoya la idea que la pérdida de altura de las coronas reduce el estrés cervical y el desarrollo de NCCLs en poblaciones arqueológicas.

PALABRAS CLAVE: lesiones cervicales no cariosas, abfracción, desgaste dental, precolombina, Chile. 


\section{REFERENCES}

Aaron, G. M. The prevalence of non-carious cervical lesions in modern and ancient American skulls: lack of evidence for an occlusal etiology. M.S. thesis. Florida, University of Florida, 2004.

Aubry, M.; Maffart, B.; Donat, B. \& Brau, J. J. Brief communication: Study of noncarious cervical tooth lesions in samples of prehistoric, historic, and modern populations from the South of France. Am. J. Phys. Anthropol., 121(1):10-4, 2003.

Bartlett, D.; Ganss, C. \& Lussi, A. Basic Erosive Wear Examination (BEWE): a new scoring system for scientific and clinical needs. Clin. Oral Investig., 12(Suppl. 1):S658, 2008.

Bartlett, D. W. \& Shah, P. A critical review of non-carious cervical (wear) lesions and the role of abfraction, erosion, and abrasion. J. Dent. Res., 85(4):306-12, 2006.

Benazzi, S.; Nguyen, H.; Schulz, D.; Grose, I. R.; Gruppioni, G.; Hublin, J. J. \& Kullmer, O. The evolutionary paradox of tooth wear: simply destruction or inevitable adaptation? PLoS One, 8(4):e62263, 2013.

Buikstra, J. E. \& Ubelaker, D. H. (Eds.). Standards for Data Collection from Human Skeletal Remains. Fayetteville, Arkansas Archaeological Survey Research Series N44, 1994.

Coppa, A.; Bondioli, L.; Frayer, D.; Macchiarelli, R.; Nava, \& A. Tartaglia, G. Noncarious cervical tooth lesions (NCTL) from the early Neolithic site of Mehrgarh. 76th Annual meeting of the American Association of Physical Anthropologist, Philadelphia, Pennsylvania, 2007. p.91.

Costa, M. Reconstitución física y cultural de la población tardía del cementerio Quitor 6 (San Pedro de Atacama). Estud. Atacam., 9:107-35, 1988.

Costa, M.; \& Llagostera A. Coyo-3: Momentos finales del Período Medio en San Pedro de Atacama. Estud. Atacam, 11: 73-107, 1994.

Deter, C. A. Gradients of occlusal wear in hunter-gatherers and agriculturalists. Am. J. Phys. Anthropol., 138(3):24754, 2009.

d'Incau, E.; Couture, C. \& Maureille, B. Human tooth wear in the past and the present: tribological mechanisms, scoring systems, dental and skeletal compensations. Arch. Oral Biol., 57(3):214-29, 2012.

Eshed, V.; Gopher, A. \& Hershkovitz, I. Tooth wear and dental pathology at the advent of agriculture: new evidence from the Levant. Am. J. Phys. Anthropol., 130(2):145-59, 2006.
Ganss, C.; Klimek, J. \& Borkowski, N. Characteristics of tooth wear in relation to different nutritional patterns including contemporary and medieval subjects. Eur. J. Oral Sci., 110(1):54-60, 2002.

Grippo, J. O. Abfractions: a new classification of hard tissue lesions of teeth. J. Esthet. Dent., 3(1):14-9, 1991.

Grippo, J. O.; Simring, M. \& Coleman, T. A. Abfraction, abrasion, biocorrosion, and the enigma of noncarious cervical lesions: a 20-year perspective. J. Esthet. Restor. Dent., 24(1):10-23, 2012.

Hinton, R. J. Form and patterning of anterior tooth wear among aboriginal human groups. Am. J. Phys. Anthropol., 54(4):555-64, 1981.

Hubbe, M.; Torres-Rouff, C.; Neves, W. A.; King, L. M.; DaGloria, P. \& Costa, M. A. Dental health in Northern Chile's Atacama oases: evaluating the Middle Horizon (AD 5001000) impact on local diet. Am. J. Phys. Anthropol., 148(1):62-72, 2012.

Kaidonis, J. A.; Richards, L. C. \& Townsend, G. C. Nature and frequency of dental wear facets in an Australian aboriginal population. J. Oral. Rehabil., 20(3):333-40, 1993.

Kaidonis, J. A. Tooth wear: the view of the anthropologist. Clin. Oral. Investig., 12(Suppl. 1):S21-6, 2008.

Kaidonis, J. A.; Ranjitkar, S.; Lekkas, D. \& Townsed, G. C. An anthropological perspective: another dimension to modern dental wear concepts. Int. J. Dent., 2012:741405, 2012.

Kaifu, Y. Changes in the pattern of tooth wear from prehistoric to recent periods in Japan. Am. J. Phys. Anthropol., 109(4):485-99, 1999.

Kaifu, Y. Tooth wear and compensatory modification of the anterior dentoalveolar complex in humans. Am. J. Phys. Anthropol., 111(3):369-92, 2000.

Kaifu, Y.; Kasai, K.; Townsend, G.C. \& Richards, L.C. Tooth wear and the "design" of the human dentition: a perspective from evolutionary medicine. Am. J. Phys. Anthropol., Suppl. 37:47-61, 2003.

Kieser, J. A.; Dennison, K. J.; Kaidonis, J. A.; Huang, D.; Herbison, P. G. P. \& Tayles, N. G. Patterns of dental wear in the early Maori dentition. Int. J. Osteoarchaeol., 11(3):206-17, 2001.

Kitchin, P. C. The prevalence of tooth root exposure and the relation of the extent of such exposure to degree of abrasion in different age classes. J. Dent. Res., 20:56581, 1941. 
URZÚA, I.; CABELLO, R.; RODRÍGUEZ, G.; SÁNCHEZ, J.; FALEIROS, S. \& PACHECO, A. Absence of non-carious cervical lesions (NCCLs) in a Chilean pre-Columbian sample with severe occlusal tooth wear. Int. J. Odontostomat., 9(1):59-64, 2015.

Larsen, C. S. Bioarchaeology: Interpreting Behavior from the Human Skeleton. 3th ed. Cambridge, Cambridge University Press, 1999.

Lee, W. C. \& Eakle, W. S. Possible role of tensile stress in the etiology of cervical erosive lesions of teeth. $J$. Prosthet. Dent., 52(3):374-80, 1984.

Lewis, K. J. \& Smith B. G. The relationship of erosion and attrition in extensive tooth tissue loss. Case reports. Br. Dent. J., 135(9):400-4, 1973.

Litonjua, L. A.; Andreana, S.; Bush, P. J. \& Cohen, R. E. Tooth wear: attrition, erosion, and abrasion. Quintessence Int., 34(6):435-46, 2003a.

Litonjua, L. A.; Andreana, S.; Bush, P. J; Tobias, T. S.; \& Cohen, R. E. Noncarious cervical lesions and abfractions: a re-evaluation. J. Am. Dent. Assoc., 134(7):845-50, 2003b.

Litonjua, L. A.; Bush, P. J.; Andreana, S.; Tobias, T. S. \& Cohen, R. E. Effects of occlusal load on cervical lesions. J. Oral. Rehabil., 31(3):225-32, 2004.

McEvoy, S. A.; Mitchell, R. J. \& Powell, M. L. Wedgeshaped cervical dental lesions in two prehistoric Native American populations. Am. J. Phys. Anthropol., Suppl., 22:162, 1996.

Michael, J. A.; Townsend, G. C.; Greenwood, L. F. \& Kaidonis, J. A. Abfraction: separating fact from fiction. Aust. Dent. J., 54(1):2-8, 2009.

Molnar, S. Human tooth wear, tooth function and cultural variability. Am. J. Phys. Anthropol., 34(2):175-89, 1971.

Molnar, P. Extramasticatory dental wear reflecting habitual behavior and health in past populations. Clin. Oral. Investig., 15(5):681-9, 2011.

Pindborg, J. J. Chronic mechanical injuries. In: Pindborg, J. J. (Ed.). Pathology of the dental hard tissues. Copenhagen, Munksgaard, 1970a. pp.294-311.

Pindborg, J. J. Chemical and physical injuries. In: Pindborg, J. J. (Ed.). Pathology of the dental hard tissues. Copenhagen, Munksgaard, 1970b. pp.31225.

Ritter, A. V.; Grippo, J. O.; Coleman, T. A. \& Morgan, M. E. Prevalence of carious and non-carious cervical lesions in archaeological populations from North America and Europe. J. Esthet. Restor. Dent., 21(5):324-35, 2009.

Senna, P.; Del Bel Cury, A. \& Rösing, C. Non-carious cervical lesions and occlusion: a systematic review of clinical studies. J. Oral Rehabil., 39(6):450-62, 2012.
Smith, P. Diet and attrition in the Natufians. Am. J. Phys. Anthropol., 37(2):233-8, 1972.

Smith, B. H. Patterns of molar wear in hunger-gatherers and agriculturalists. Am. J. Phys. Anthropol., 63(1):3956, 1984.

Takehara, J.; Takano, T.; Akhter, R. \& Morita, M. Correlations of noncarious cervical lesions and occlusal factors determined by using pressuredetecting sheet. J. Dent., 36(10):774-9, 2008.

Torres-Rouff, C. \& Hubbe, M. The sequence of human occupation in the Atacama Oases, Chile: a radiocarbon chronology based on human skeletal remains. Lat. Am. Antiq., 24(3):330-44, 2013.

Vasconcelos, A.; Pola, I.; Poiate, E. \& Gomes W. Abfraction lesions reviewed: Current concepts. Rev. Gaucha Odontol., 56(3):321-6, 2008.

Wood, I.; Jawad, Z.; Paisley, C. \& Brunton, P. Non-carious cervical tooth surface loss: a literature review. J. Dent., 36(10):759-66, 2008.

Correspondence to: Jenny Sánchez González

Faculty of Dentistry

Universidad de Chile

Sergio Livingstone Pohlhammer 943

Independencia

Santiago

CHILE

Email: drajennysanchez@gmail.com

Received: 22-10-2014

Accepted: 02-03-2015 